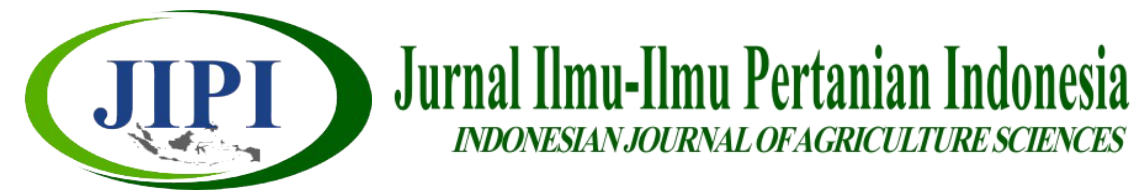

\title{
MUTU BUAH JERUK KALAMANSI PADA BERBAGAI TINGKAT SERANGAN PENYAKIT KUDIS
}

\author{
Kusmea Dinata $^{1 *}$ dan Taufik Hidayat ${ }^{1}$ \\ ${ }^{1}$ Balai Pengkajian Teknologi Pertanian Bengkulu \\ Jalan Irian Km 6,5. Kelurahan Semarang Kota Bengkulu \\ * Corresponding Author : dinata.kusmea@gmail.com
}

\begin{abstract}
[FRUIT QUALITIES OF CALAMANSI UNDER DIFFERENT SCAB DISEASE SEVERITIES]. Citrus scab caused by Elsinoë fawcettii dan Elsinoë australis fungi is an important disease for calamansi lime. The pathogen can result creamy-yellowish, raised, rounded, corky scabs appear on the rind surface of the fruit that reduces marketabilityof the fruit. The objective of this study was to evaluate the development and intensity of scab and their effects on the physical and chemical qualities of calamansi fruits. The observations were made on 30 fruit samples collected from farmer's calamansi orchard for the development and intensity of disease symptoms, fruit appearances, juice content, and total soluble solids of the juice. The results showed that the pathogen began to attack on early fruit set phase. The intensity of the disease at the beginning of the observation was $11.06 \%$ and increased to $58.18 \%$ with an average rate of attack intensity of $14.54 \%$. The disease reduced the fruit weight, fruit diameter, juice volume and total soluble solid levels.
\end{abstract}

Keyword: E. fawcetti, E. australis, fruit appearance, fruit set, juice content, total soluble solid

\begin{abstract}
ABSTRAK
Penyakit kudis yang ditimbulkan oleh jamur Elsinoë fawcettii dan Elsinoë australis merupakan penyakit penting pada tanaman jeruk kalamansi. Patogen tersebut dapat menyebabkan kulit buah berwarna putih kekuningan, agak menonjol seperti gabus mirip seperti kudis sehingga menurunkan nilai jual buah. Penelitian ini bertujuan untuk mengevaluasi perkembangan dan intensitas penyakit kudis serta pengaruhnya terhadap mutu buah jeruk kalamansi. Pengamatan dilakukan terhadap perkembangan dan intensitas gejala serangan penyakit kudis, penamapakan buah, kandungan jus, dan total padatan terlarut (TPT) dari 30 sampel tanaman yang diambil dari kebun jeruk kalamansi petani. Hasil penelitian menunjukkan bahwa patogen mulai menyerang pada fase fruitset. Intensitas serangan penyakit pada awal pengamatan mencapai $11,06 \%$ dan meningkat hingga $58,18 \%$ dengan rata-rata laju serangan sebesar $14,54 \%$. Penyakit kudis menurunkan bobot buah, diameter buah, volume jus dan kadar total padatan terlarut.
\end{abstract}

Kata kunci: E. fawcetti, E. australis, kenampakan buah, fruit set, kandungan jus, total padatan terlarut 


\section{PENDAHULUAN}

Jeruk kalamansi kalamansi (Citrus microcarpa) merupakan komoditas yang telah berkembang di Provinsi Bengkulu terutama di Kabupaten Bengkulu Tengah dan Kota Bengkulu. Pengembangan budidaya di tingkat petani dimulai pada tahun 2010. Aroma yang harum dan khas, membuat jeruk kalamasi mulai dilirik konsumen baik dalam bentuk segar maupun olahan berupa sirup. Jeruk kalamansi kaya senyawa flavonoid di antaranya asam askorbat dan asam sitrat dan rendah kandungan gula (Yo \& Lin, 2005; Lou et al., 2014). Beberapa pengrajin usaha makanan di Bengkulu telah membuat olahan sirup jeruk kalamansi yang sudah dalam bentuk kemasan. Saat ini permintaan olahan sirup tidak hanya diminati oleh konsumen lokal tapi juga konsumen dari luar provinsi.

Produksi buah jeruk kalamansi segar masih terbatas. Kebutuhan bahan baku jeruk kalamansi semakin meningkat seiring dengan permintaan pasar terhadap olahan sirup. Terbatasnya produksi jeruk kalamansi salah satunya disebabkan adanya serangan penyakit. Penyakit yang banyak menyerang buah jeruk kalamansi adalah penyakit kudis yang disebabkan oleh jamur patogen. Hasil observasi awal pada kebun petani jeruk kalamansi di Kabupaten Bengkulu Tengah, intensitas penyakit mencapai 50\%. Patogen ini menyerang buah jeruk mulai dari fase buah pentil hingga buah dewasa.

Terdapat dua jenis spesies jamur penyebab penyakit kudis pada buah jeruk yaitu Elsinoë fawcettii dan Elsinoë australis (Hyun et al., 2009; Xin et al, 2014). Penyakit ini awalnya terjadi di negara Amerika Selatan termasuk Argentina, Bolivia, Brasil, Equador, Paraguai, dan Uruguai (Chung, 2011). Serangan penyakit kudis buah jeruk banyak terjadi pada daerah beriklim lembab (Kunta et al, 2013). Gejala serangan terjadi pada jaringan muda seperti daun, tunas dan buah dari jenis jeruk yang rentan (Nelson, 2008). Gejala pada buah ditandai dengan terdapat bercak pada permukaan kulit buah berwarna putih kekuningan, agak menonjol seperti gabus mirip seperti kudis. Serangan penyakit ini dapat mengakibatkan berkurangnya kualitas dan nilai jual pada beberapa jeruk segar komersial, karena penampilan buah yang kurang menarik (Bushong \& Timmer, 2000; Hyun et al., 2009).

Tingginya insidensi serangan penyakit kudis di areal pertanaman jeruk kalamansi menunjukkan bahwa pengetahuan petani terhadap penyakit tersebut masih rendah. Selama ini usaha pengolahan sirup hanya mengandalkan produksi buah jeruk kalamansi dari petani lokal. Dengan demikian, kerusakan yang ditimbulkan oleh penyakit kudis selain merugikan petani, juga berdampak pada penurunan kualitas dan kuantitas produk hasil olahan.
Penelitian tentang penyakit kudis buah jeruk masih terbatas di Indonesia, apalagi pada tanaman jeruk kalamansi, sehingga perlu adanya kajian untuk mendapatkan gambaran tentang perkembangan serangan penyakit kudis pada jeruk kalamansi, serta pengaruh yang ditimbulkan akibat serangan penyakit tersebut. Penelitian ini bertujuan untuk mengevaluasi perkembangan penyakit kudis dan pengaruhnya terhadap mutu buah jeruk kalamansi.

\section{METODE PENELITIAN}

Penelitian ini dilaksanakan pada kebun jeruk petani yang berlokasi di Desa Taba Jambu, Kecamatan Pondok Kelapa, Kabupaten Bengkulu Tengah dari bulan Agustus sampai dengan Desember 2016. Penelitian dilaksanakan dengan metode survei pada kebun petani melalui pengamatan gejala serangan dan intensitas serangan penyakit kudis di areal pertanaman jeruk kalamansi. Pengamatan dilakukan setiap bulan terhadap 30 sampel tanaman dari lima titik yang dipilih secara diagonal. Intensitas serangan penyakit ditetapkan berdasarkan skor gejala serangan kudis pada buah (Gambar 1 dan Tabel 1).

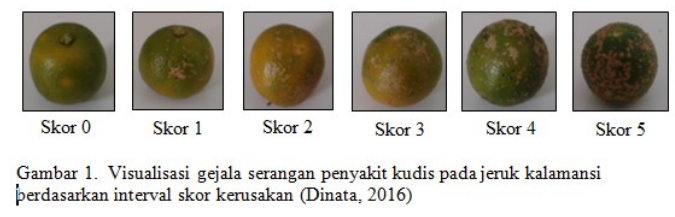

Tabel 1. Penentuan skor serangan penyakit kudis buah jeruk kalamansi

\begin{tabular}{cc}
\hline Skor & $\begin{array}{c}\text { Interval luas bercak kudis } \\
(\%)\end{array}$ \\
\hline 0 & 0 \\
1 & $>0-10$ \\
2 & $>10-20$ \\
3 & $>20-40$ \\
4 & $>40-70$ \\
5 & $>70$ \\
\hline
\end{tabular}

Data hasil skoring gejala serangan kudis kemudian digunakan untuk menghitung intensitas serangan penyakit dengan mengunakan rumus Townsed \& Humberger (Agrios, 1997).

$$
I=\frac{\sum n i \times v i}{N \times z} \times 100 \%
$$

\section{Keterangan :}

ni : pengamatan ke-i

vi : nilai skor pada pengamatan ke-i

$\mathrm{N}$ : Jumlah sampel yang diamati

$\mathrm{Z} \quad$ : nilai skor tertinggi

Pengukuran mutu buah jeruk dilakukan di laboratorium Pascapanen BPTP Bengkulu. Pengambilan sampel buah dipilih secara sengaja sesuai katagori serangan 
penyakit kudis yang telah ditentukan. Mutu buah yang diukur adalah mutu fisik buah meliputi bobot buah menggunakan timbangan digital, diameter buah dengan jangka sorong, kadar jus dengan gelas ukur, serta total padatan terlarut (TPT) dengan alat refractometer. Analisis regresi linier dilakukan untuk menjelaskan hubungan antara tingkat dan kualitas buah.

\section{HASIL DAN PEMBAHASAN}

\section{Kondisi pertanaman}

Umur tanaman jeruk kalamansi pada lokasi observasi di Desa Taba Jambu Kabupaten Bengkulu Tengah yaitu sekitar 5-7 tahun. Pada pertanaman jeruk ditemukan dua penyakit yang dominan menyerang tanaman jeruk kalamansi yaitu penyakit diplodia (blendok) dan penyakit kudis buah jeruk. Hasil observasi awal diketahui intensitas serangan penyakit kudis buah rerata mencapai 50\%. Belum ada usaha pengendalian yang dilakukan dalam mengurangi serangan penyakit kudis buah oleh petani. Pengetahuan petani terhadap serangan hama dan penyakit jeruk masih sangat terbatas, hal ini menyebabkan pengendalian yang dilakukan masih belum tepat sasaran.

Usaha budidaya yang dilakukan oleh petani belum sepenuhnya mengikuti pengelolaan kebun jeruk yang dianjurkan. Jarak tanam yang digunakan pada kebun milik petani $2,5 \times 3 \mathrm{~m}$. Sebagian besar para petani belum melakukan pemangkasan, pemberian kompos serta pengendalian OPT yang tepat. Pemupukan dilakukan setiap 6 bulan sekali dengan pupuk NPK (15:15:15) dosis $2 \mathrm{~kg} /$ batang/tahun. Rekomendasi pemupukan untuk jeruk kalamansi memang belum tersedia. Kondisi jarak tanam yang rapat membuata iklim mikro tanaman menjadi lembab, serta intensitas cahaya yang masuk berkurang. Hal ini membuat serangan penyakit kudis menjadi tinggi. Pemangkasan yang belum baik dan konsisten akan memperparah terjadinya serangan penyakit kudis karena juga berhubungan dengan faktor intensitas cahaya dan kelembaban mikro tanaman.

\section{Gejala serangan penyakit}

Hasil pengamatan gejala serangan penyakit kudis pada buah jeruk kalamasi yaitu terdapat bercak kudis kecil pada buah yang dimulai pada fase fruitset, pada umur 1 minggu sejak bunga mekar. Buah yang terserang lebih awal mengakibatkan buah gugur. Seiring dengan perkembangan buah, bercak menebal menonjol seperti kudis yang menyebar pada permukaan kulit buah. Jaringan tanaman yang terserang membentuk bercak kudis seperti gabus (Fan et al., 2017) Pada kondisi serangan bobot buah tidak berkembang dengan baik, terutama ukuran buah yang kecil dan tekstur buah yang keras. Pada daun jeruk kalamansi tidak terlihat gejala serangan bercak seperti gejala serangan pada jenis jeruk lainnya. Hasil penelitian Timmer et al (2000) melaporkan bahwa tidak semua biotipe jamur penyebab kudis menyerang daun, spesies $E$. australis hanya menyerang buah.

Jamur penyebab penyakit kudis ini mampu membentuk intrahyphal, yang merupakan suatu bentuk mekanisme pertahanan hidup pada kondisi tertentu sebagai respon terhadap kerusakan sel atau mutasi genetik (Bowman et al., 2006). Pembentukan intrahyphal $E$. fawcettii bisa berfungsi sebagai mekanisme regenerasi jamur di bawah kondisi yang tidak menguntungkan (Kim dan Hyun, 2006). Terbentunya intahyphal ini membuat jamur mampu bertahan dan siap menyerang tanaman pada saat kondisi optimum bagi pertumbuhannya.

\section{Perkembangan serangan penyakit}

Perkembangan intensitas penyakit dilakukan dengan pengamatan buah jeruk selama satu periode pembuahan pada setiap satu bulan sekali setelah bunga mekar (Gambar 2). Perkembangan penyakit kudis pada buah jeruk kalamansi semakin meningkat seiring dengan umur buah, dengan rata-rata laju intensitas serangan sebesar $14,54 \%$. Pada awal bulan petama intensitas serangan sudah cukup tinggi, pada fase ini banyak buah yang gugur karena umur buah yang masih muda. Perkembangan bercak kudis terus berkembang menutupi permukaan buah. Buah yang terserang lebih awal perkembangan bercak kudisnya lebih cepat yang membuat buah tidak berkembang dengan baik, ukuran buah mengecil dan tekstur buah agak keras.

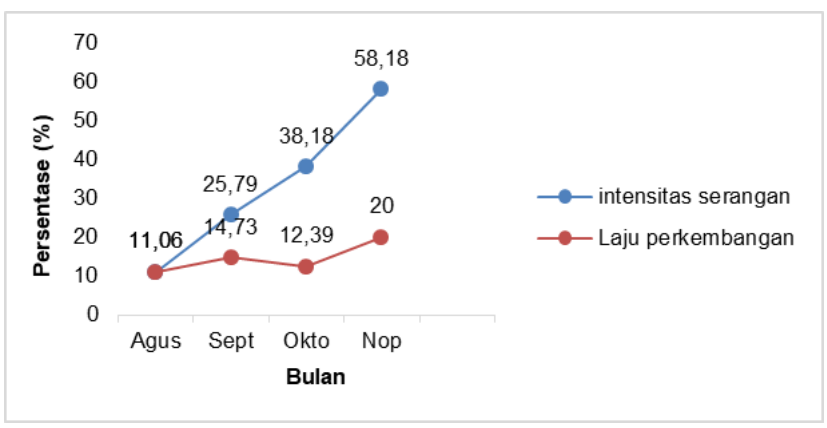

Gambar 2. Laju perkembangan dan intensitas serangan penyakit kudis buah jeruk pada satu periode pembuahan dari bulan Agustus-Desember 2016

Tingginya intensitas serangan penyakit memiliki keterkaitan dengan tingkat curah hujan bulanan (Gambar 3). pada bulan Agustus sampai November curah hujan cukup tinggi karena sudah memasuki musim hujan. Rata-rata curah hujan bulanan pada bulan tersebut yaitu $414,25 \mathrm{~mm}$, dengan puncak 
tertinggi pada saat pengamatan di bulan November. Laju perkembangan penyakit tertinggi terjadi pada bulan Oktober sampai November, kondisi ini didukung curah hujan yang tinggi pada saat itu. Hal ini menunjukkan bahwa kondisi hujan sangat kondusif bagi perkembangan penyakit kudis pada buah jeruk kalamansi. Spora jamur penyebab kudis diproduksi oleh jaringan tanaman yang terinfeksi hanya memerlukan kondisi basah selama 1-2 jam dan spora tersebut selanjutnya disebarkan ke daun atau buah melalui percikan air hujan (Gopal et al., 2014). Jika kondisi basah berlanjut, proses infeksi pada jaringan daun atau buah akan terjadi dalam waktu 3-4 jam (Timmer et al., 2000; Dewdney, 2012) dan infeksi maksimum terjadi ketika kondisi basah berlangsung hingga 12 jam (Agostini et al., 2003).

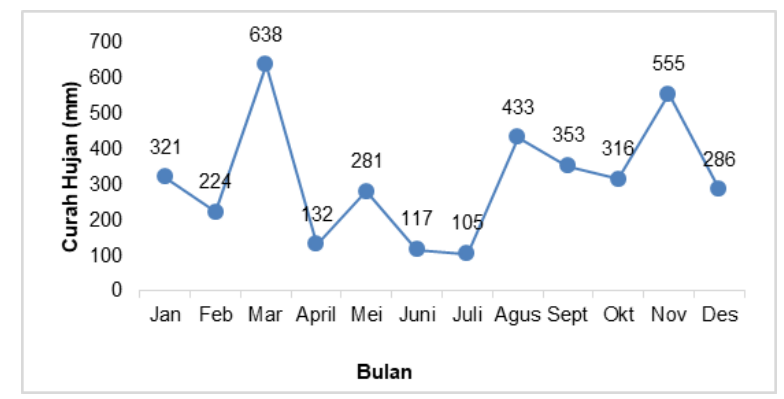

Gambar 3. Rata-rata data curah hujan bulanan Kota Bengkulu tahun 2016 (BPS Kota Bengkulu 2017)

\section{Hubungan antara intensitas serangan penyakit dengan mutu buah}

Secara umum, mutu buah jeruk kalamansi mengalami penurunan seiring dengan peningkatan intensitas serangan penyakit kudis. Persamaan regresi $\mathrm{Y}=22,29-2,77 \mathrm{X}\left(\mathrm{R}^{2}=0,73\right)$ menunjukkan bahwa penyusutan bobot buah/tanaman mencapai 2,77 $\mathrm{g}$ pada setiap peningkatan skor intensitas serangan penyakit kudis. Demikian pula terlihat persamaan regresi pada diameter buah, kandungan jus, dan nilai TPT dengan nilai penyusutan berturut adalah $0,17 \mathrm{~cm}, 0,74 \mathrm{~mL}$, dan $0,22{ }^{\circ}$ brix pada setiap peningkatan skor intensitas serangan (Gambar 4). Hal ini menunjukkan bahwa serangan penyakit kudis mempengaruhi setiap variabel mutu buah yang saling berhubungan dan nilai penurunannya berbanding lurus. Penurunan kadar jus buah dipengaruhi oleh penurunan bobot dan diameter buah. Buah yang terserang kudis memiliki tekstur keras dan kulitnya tebal, sehingga rongga penyimpanan cairan buah menjadi berkurang yang tentunya mengurangi kadar jus buah.
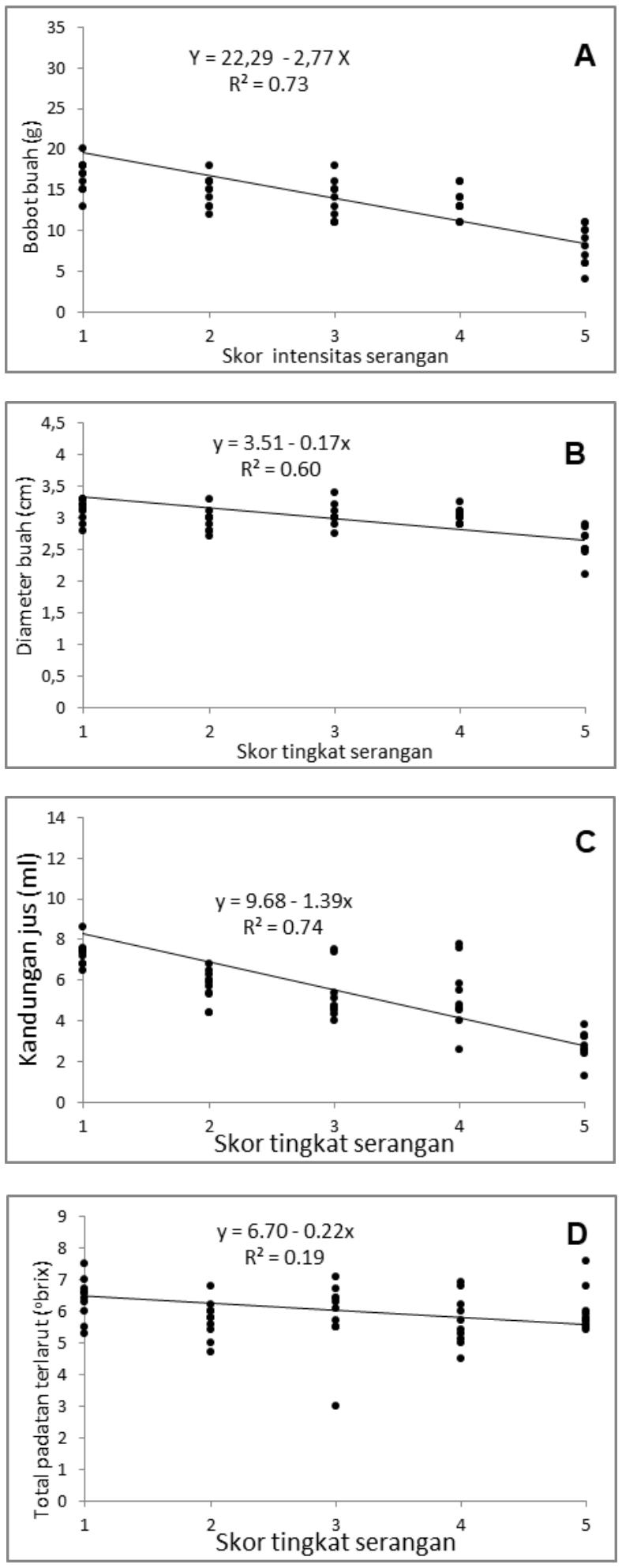

Gambar 4. Hubungan antara intensitas serangan penyakit kudis dan mutu buah jeruk kalamansi 
Pengukuran variabel mutu buah jeruk terhadap skor katagori intensitas serangan dilakukan di laboratorium. Hasil analisis mutu fisik dan kimia buah jeruk disajikan pada Tabel 2. Intensitas serangan penyakit kudis menyebabkan penurunan bobot buah, diameter buah dan volume jus. Variabel kandungan jus yang dihasilkan berbanding lurus dengan hasil pengukuran bobot buah dan diameter buah. Pada intensitas dengan skor katagori 1 terjadi penurunan signifikan terhadap bobot buah dan volume jus dan terus menurun, kemudian meningkat lagi pada saat skor katagori 5. Sementara untuk variabel diameter buah dan kadar TPT laju penurunannya sedikit lebih landai dibandingkan dengan variabel bobot buah dan volume jus. Hasil pengukuran didapatkan bahwa serangan penyakit kudis mampu menurunkan bobot buah $67,71 \%$, diameter buah $32,43 \%$, volume jus $75,04 \%$ dan kadar TPT $20,75 \%$ bila dibandingkan dengan buah jeruk yang normal. Dari uraian tersebut dapat dikatakan serangan penyakit kudis ini termasuk penyakit utama pada tanaman jeruk kalamansi yang perlu mendapat perhatian yang serius.

Tabel 2.Hasil analisis mutu fisik dan kimia buah jeruk kalamansi berdasarkan skor katagori intensitas serangan penyakit kudis

\begin{tabular}{|c|c|c|c|c|c|}
\hline \multirow[b]{2}{*}{ Skor } & \multirow[b]{2}{*}{$\begin{array}{l}\text { Katagori } \\
\text { Intensitas } \\
\text { Serangan }\end{array}$} & \multicolumn{4}{|c|}{ Mutu buah } \\
\hline & & $\begin{array}{c}\text { Bobot } \\
\text { buah }(g)\end{array}$ & $\begin{array}{c}\text { Diameter } \\
\text { buah } \\
(\mathrm{cm})\end{array}$ & $\begin{array}{l}\text { Volume } \\
\text { jus (mL) }\end{array}$ & $\begin{array}{l}\text { TPT } \\
\text { (brix) }\end{array}$ \\
\hline 0 & $\begin{array}{l}\text { Tidak ada } \\
\text { serangan }\end{array}$ & 25,4 & 3,7 & 11,1 & 7,18 \\
\hline 1 & $\begin{array}{l}\text { Luas bercak } 0-10 \\
\%\end{array}$ & 16,7 & 3,1 & 7,33 & 6,39 \\
\hline 2 & $\begin{array}{l}\text { Luas bercak }>10 \text { - } \\
20 \%\end{array}$ & 14,8 & 3 & 5,67 & 6 \\
\hline 3 & $\begin{array}{l}\text { Luas bercak }>20 \text { - } \\
40 \%\end{array}$ & 13,6 & 2,9 & 5,22 & 5,87 \\
\hline 4 & $\begin{array}{l}\text { Luas bercak }>40 \text { - } \\
70 \%\end{array}$ & 13,4 & 2,9 & 5,18 & 5,73 \\
\hline 5 & $\begin{array}{l}\text { Luas } \\
\text { bercak }>70 \% \text {, } \\
\text { (buah kecil dan } \\
\text { tidak normal) }\end{array}$ & 8,2 & 2,5 & 2,77 & 5,69 \\
\hline
\end{tabular}

Kadar jus dan kadar TPT merupakan komponen paling utama yang harus diperhatikan karena akan berpengaruh terhadap mutu hasil olahan sirup. Menurut pengusaha olahan jeruk, biasanya untuk mendapatkan 1 liter sari buah jeruk mereka membutuhkan $2,5 \mathrm{~kg}$ buah jeruk yang normal, sedangkan kalau buah jeruk yang terserang kudis membutuhkan lebih kurang $4 \mathrm{~kg}$ buah jeruk segar. Informasi tersebut membenarkan adanya penurunan kadar jus buah jeruk kalamasi sebanyak 37,5\% akibat serangan penyakit kudis. Buah jeruk Kalamansi yang normal memiliki bentuk buah gepeng dengan ukuran tinggi $2,4-3,1 \mathrm{~cm}$, diameter
$2,6-3,5 \mathrm{~cm}$, dan bobot buah antara $13,5-25,0 \mathrm{~g}$, kadar TPT 7,5 - 8,0 brix (Ditjen Hortikultura, 2014).

\section{KESIMPULAN}

Penyakit kudis pada buah jeruk kalamansi mulai menyerang pada fase buah fruitset kemudian perkembangan penyakit meningkat seiring dengan umur buah dan didukung kondisi lingkungan yang optimum. Penyakit kudis merupakan panyakit utama pada jeruk kalamansi, karena serangan penyakit kudis mampu menurunkan mutu fisik dan kimia buah jeruk kalamansi jika dibandingkan buah jeruk normal.

\section{SANWACANA}

Ucapan terima kasih disampaikan kepada Bapak Prawoto sebagai pemilik kebun jeruk Kalamansi yang telah membantu dan memfasilitasi selama pelaksanaan penelitian penyakit kudis ini.

\section{DAFTAR PUSTAKA}

Agostini. J.P., Bushong. P.M, Bhatia. A., Timmer, L.W. (2003). Influence of environmental factors on severity of citrus scab and melanose. J.Plant Dis., 87, 1102-1106.

Agrios, G.N. (1997). Plant Pathology. Academic Pr., San Diego, United States.

Bowman, S., Piwowar, A., Dabbous, M.A., Vierula, J., Free, S.J. (2006). Mutational analysis of the glycosylphosphatidylinositol (GPI) anchor pathway demonstrates that GPI-anchored proteins are required for cell wallbiogenesis and normal hyphal growth in Neurospora crassa. Eukaryot. Cells, 5(3), $587-600$.

BPS. (2017). Curah Hujan Kota Bengkulu tahun 2011-2016. https:/bengkulukota.bps.go.id/dynamictable/ 2018/01/11/62/curah-hujan-kota-bengkulu-20112016. html. [diakses 30 September 2018].

Bushong, P. M. \& Timmer, L. W. (2000). Evaluation of postinfection control of citrus scab and melanose with benomyl, fenbuconazole, and azoxystrobin. $J$. Plant Dis. (84), 1246-1249.

Chen. P.S., Wang, L.Y., Chen, Y.J., Tzeng, K.C., Chang, S.C. \& Chung, Lee, M.H. (2012). Understanding cellular defence in kumquat and calamondin to citrus canker caused by Xanthomonas citri subsp. Citri. Physiological and Molecular Plant Pathology, 79, 1-12.

Chung. K.R. (2011). Elsinoë fawcettii and Elsinoë australis: The fungal pathogens causing citrus scab. Molecular Plant Pathology, 12, 123-135.

Dewdney. M, (2012). Citrus Disase Spotlight. http:// www.crec.ifas.ufl.edu/extension/ trade_journals/2012/2012_Mar_citrus_scab.pdf [diakses 9 Februari 2018] 
Fan X.L, Barreto, R.W., Groenewald, J.Z., Bezerra, J.D.P., Pereira, O.L., Cheewangkoon, R., Mostert, L., Tian, C.M., Crous, P.W. (2017). Phylogeny and taxonomy of the scab and spot anthracnose fungus Elsinoë (Myriangiales, Dothideomycetes). j.simyco. 17, 1-75

Gopal. K, Govindarajulu, B., Ramana, K.T.V., Kumar, C.S.K., Gopi, V., Sankar, T.G., Lakshmi, L.M., Lakshmi, T.N. \& Sarada, G. (2014). Citrus Scab (Elsinoe fawcettii): A Review. J. RRJAAS, 3 (3), 49-58

Hyun. J.W, S. H. Yi, S. J. MacKenzie, L. W. Timmer, K. S. Kim, S. K. Kang, H. M. Kwon, \& Lim, H.C. (2009). Pathotypes and Genetic Relationship of Worldwide Collections of Elsinoë spp. Causing Scab Diseases of Citrus. J. Phytopathology, 99(6), 721-728.

Kementerian Pertanian R.I. (2014). Lampiran Surat Keputusan Menteri Pertanian Nomor 06/kpts/ SR.120/D.2.7/2/2014 Tentang Deskripsi Jeruk Nipis Varietas Kalamansi FR. Kementerian Pertanian, Jakarta.

Kim, K.W. \& Hyun, J.W. (2006). Nonhost-associated proliferation of intrahyphal hyphae of citrus scab fungus Elsinoe fawcettii: Refining the perception of cell-within-a-cell organization. Micron, 38, 565 -571 .
Kunta, M, J., Rascoe, Sa, P.B., Timmer, L.W., Palm, M.E., Graça, J.V., Mangan, R.L., Malik, N.S.A., Salas, B., Satpute, A., Sétamou, M., Skaria, M. (2013). Sweet orange scab with a new scab disease "syndrome" of citrus in the USA associated with Elsinoë australis. J.Tropical Plant Pathology, 38 (3), 203-212.

Lou. S. N, Y.S. Hsu, C.T. Ho. (2014). Flavonoid compositions and antioxidant activity of calamondin extracts prepared using different solvents. $J$. FDA. 22(3), 1-6.

Nelson, S. (2008). Citrus Scab. Department of Plant and Environmental Protection Sciences. University of Hawai.

Timmer, L.W., Garnsey, S.M., Graham J.H. (2000). Compendium of Citrus Diseases. American Phytopathological Society, USA.

Xin. H, Huang., F, Zhang. T.Y \& Xu, J.G. (2014). Pathotypes and Genetic Diversity of Chinese Collections of Elsinoë fawcettii Causing Citrus Scab. Journal of Integrative Agriculture, 13(6), 1293-1302.

Yo. S.P. \& Lin, C.H. (2005). Qualitative and Quantitative Composition of the Flavour Components of Taiwan Calamondin and Philippine Calamansi Fruit. J.Hort.Sci., 69(3), 117-124. 